\title{
Gerakan Nasionalisme Islam Sebelum Kemerdekaan RI
}

\section{Mawar Febrianti}

Mahasiswa pasca Sarjana Universitas Paramadina, Indonesia

\section{Abstract}

Nationalism among Indonesian Muslims has grown since a number of sultans in the homeland against the Dutch. The resistance of the empire was a physical war against the Dutch. After the Dutch conquered almost all local sultanates and kingdoms, so that the Dutch controlled Indonesia completely, the form of resistance then changed. Changes in the form of struggle are marked by the birth of Islamic movements, both in the form of madrasa (schools), mass organizations, and political parties. Awareness of the spirit of nationalism was formed from the age of the empire, which then continued to grow among Islamic mass organizations, eventually becoming more crystallized within the bodies of political parties.

\section{Keywords}

gerakan; nasionalisme; Indonesia; kemerdekaan Islam

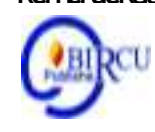

\section{Pendahuluan}

Muslim Indonesia telah menjadi roh bagi bangkitnya sejumlah pergerakan nasional dalam melawan penjajah dan merebut kemerdekaan, pernyataan tersebut tidak bisa dibantah karena sejarah telah membuktikan tentang sepak terjang dan peranan umat Islam dalam merebut kemerdekaan Republik Indonesia.

Bangkitnya gerakan-gerakan nasional dan gerakan Islam di Indonesia, tidak berbenturan karena memiliki kesamaan, sama-sama di latarbelakangi dari keinginan melawan penjajahan Barat, atau lebih tegasnya melawan kapitalisme dan imperialisme Barat. Adalah merupakan sifat orang Islam yang sungguh-sungguh menjalankan ke-islamanannya, siapapun dia, dari suku dan ras apapun asalnya, maka dia harus membela negaranya dan mencintai bangsanya, karena di dalam al-Quran dan Hadist terdapat anjuran tersebut, hubbul wathon minal iman mencintai negeri itu adalah bagian dari iman

Sayangnya di era sekarang, di tengah gencarnya gerakan Islamisasi dan hijrah, banyak orang yang menyangsikan jiwa nasionalisme dan kecintaan umat Islam terhadap NKRI, selain dari non muslim, bahkan ada juga dari beberapa muslim itu sendiri. Perlu ditekankan lagi bahwa muslim sejati adalah yang mencintai negaranya, apalagi Ideologi Pancasila dan UUD 45 sangat tidak bertentangan dengan syariat Islam, maka gerakan radikal yang ingin mengganti ideologi Pancasila tidak boleh ada dan berkembang di Indonesia.

Dari pernyataan penulis di atas, melalui paper ini penulis ingin menekankan kembali kecintaan umat Islam terhadap NKRI, tentang bagaimana keterlibatan dan peran serta umat Islam dalam melawan penjajah dan merebut kemerdekaan, dalam sebuah paper dengan judul "Gerakan Nasionalisme Islam Sebelum Kemerdekaan Republik Indonesia". Adapun rumusan masalah dari penulisan paper ini, terangkum dalam: 
- Bagaimana Gerakan Islam di Pulau Sumatera

- Bagaimana Gerakan Islam di Pulau Sulawesi

- Bagaimana Gerakan Islam di Pulau Jawa

- Bagaimana Gerakan Politik Islam sebelum Kemerdekaan

Adapun penulisan peper ini bertujuan untuk :

- Mengetahui keterlibatan umat Islam dalam melawan penjajahan dan merebut kemerdekaan

- Mengetahui sejarah gerakan-gerakan Islam di Indonesia sebelum kemerdekaan, khususnya di Pulau Sumatera, Pulau Sulawesi dan Pulau Jawa

- Mengetahui gerakan Politik Islam sebelum kemerdekaan RI

- Meningkatkan jiwa nasionalisme dan kecintaan kita terhadap negara kesatuan RI

Demikian, rumusan masalah dan tujuan dalam pembuatan paper ini, semoga dapat memberikan manfaat dan menambah wawasan bagi penulis khususnya, maupun bagi pembaca lainnya.

\section{Kajian Pustaka}

\section{Gerakan - Gerakan Islam Sebelum Kemerdekaan}

Kebangkitan gerakan Nasionalisme Islam di Indonesia ditandai dengan lahirnya sejumlah gerakan dalam bentuk madrasah, pesantren, organisasi sosial dan partai politik, yang bertujuan untuk memperjuangkan kemerdekaan bangsa. Kebangkitan itu sebenarnya merupakan lanjutan dari perlawanan raja-raja lokal dalam sejumlah kesultanan yang ada di tanah air. Sehingga melahirkan pejuang-pejuang muslim atau pahlawan muslim antara lain Pangeran Diponegoro dan Kyai Maja (Jawa), Sultan Ageng Tirtayasa (Banten), Sultan Hasanuddin (Makassar), Sultan Khairun (Ternate), Sultan Nuku (Tidore), Pangeran Hidayat (Banjar), Sultan Basyaruddin (Deli) Teuku Umar dan Cut Nyak Din (Aceh).

Setelah Belanda berhasil menaklukkan semua penguasa lokal, termasuk kesultanan Muslim itu, maka Belanda dengan leluasa menguasai bangsa Indonesia dalam segala aspeknya. Dalam suasana demikianlah, perjuangan kebangsaan mengambil bentuk lain, dengan lahirnya gerakan-gerakan dalam bentuk organisasi atau madrasah (sekolah), kelompok diskusi, syarikat dagang, bahkan berupa partai politik. Jadi, dengan segala coraknya itu gerakan keislaman di Indonesia bersatu dalam isu nasionalisme, yaitu melawan penjajahan untuk membangun negara Indonesia yang merdeka. ${ }^{1}$

\section{Pembahasan}

\subsection{Gerakan Islam di Pulau Sumatra}

Rentetan gerakan nasionalisme Islam di Indonesia pasca takluknya raja-raja lokal, dapat dimulai dengan menyebut kebangkitan kaum ulama di Sumatera mengahadapi kolonial Belanda. Bermula sekembalinya ke tanah air sejumlah ulama Indonesia, yakni H. Miskin dan kawan-kawan dari belajar di Hijaz pada tahun 1802. Di Minangkabau, mereka dikenal dengan gelaran "Harimau nan Salapan", yakni Haji Miskin, Tuanku di Kubu Sanang, Tuanku di Koto Ambalau, Tuanku di Ladang Lawas, Tuanku di Padang Luar, Tuanku di Galung, Tuanku di Lubuk Aur dan Tuanku Nan Renceh. Mereka mempelopori gerakan pemurnian Islam, merombak secara radikal tradisi masyarakat yang secara prinsip bertentangan dengan syariah. Maka, gerakan ini nantinya berhadapan langsung dengan Belanda yang berpihak pada kaum Adat, ketika konflik horisontal terjadi antara kauf Salaf (pemurni) dan Kaum Adat

\footnotetext{
${ }^{1}$ Soekarno, Dibawah Bendera Revolusi, (Jakarta: Panitia, 1964), Jilid I, h. 7
} 
dalam perang Paderi. Gerakan ini kemudian lebih dikenal masyarakat luas setelah didirikannya suatu Perguruan di Bonjol di bawah pimpinan Malim Basa, yang lebih masyhur dengan nama Imam Bonjol. Belanda bekerjasama dengan kaum Adat tidak senang terhadap perkembangan gerakan Salaf, dan mereka berhasil memadamkan gerakan kaum ulama tersebut dalam Perang Paderi (1822-1837). ${ }^{2}$

Kader muda kaum Salafiyah kemudian meneruskan perjuangannya dengan membentuk wadah pendidikan "Sumatera Thawalib". Pada mulanya merupakan gabungan dari perkumpulan pelajar di bawah asuhan Syekh Abdul Karim Amrullah (ayahanda Buya Hamka) di Padang Panjang, dan perkumpulan yang sama di bawah asuhan Syekh Ibrahim Musa di Parabek. Akhirnya perkumpulan yang sama di sejumlah daerah pun menggabungkan diri, dan sepakat membentuk satu organisasi pada tahun 1922 dengan nama Sumatera Thawalib yang diketuai oleh H.Jalaluddin Taib.

Gerakan madrasah tersebut mengajarkan paham kemerdekaan berpikir (berijtihad), dan kemerdekaan politik dari penjajahan Belanda. Karena itu, buku-buku yang diajarkan berisikan toleransi bermazhab, metode ijtihad, dan buku fikih lintas mazhab. Tafsir Al-Manar karya Muhammad Abduh dan Rasyid Ridha, menjadi buku wajib, karena isinya mendorong perjuangan Muslim melawan kolonialisme Barat. ${ }^{3}$

Seorang guru dari Sumatera Thawalib bernama Datuk Batuah dikenal karena sikapnya yang amat radikal menentang Belanda. Sumatera Thawalib kemudian menjadi basis berdirinya organisasi Persatuan Muslimin Indonesia (PERMI) tahun 1930. Tak lama kemudian PERMI resmi menjadi partai politik (1932), dengan sejumlah tokoh penting yakni H. Ilyas Yakob, Mokhtar Luthfi dan H. Jalaluddin Taib. Melihat ancaman dari gerakan Salafiyah muda itu, maka Belanda melalukan tekanan terhadap pergerakan tersebut. Tokohtokohnya banyak dibuang ke Digul. Akhirnya pada tahun 1937 PERMI bubar, walaupun perguruan Sumatera Thawalib sendiri tidak dibubarkan. ${ }^{4}$

Dari kalangan kaum tardisional Sumatera, gerakan keagamaan yang gigih menentang Belanda ialah Persatuan Tarbiyah Islamiyah (PERTI). Organisasi ini didirikan oleh sejumlah ulama Minangkabau pengikut mazhab Al-Syafi'iy, di bawah pimpinan Syekh Sulaiman alRasuli pada tahun 1928 di Candung. Dari segi namanya, tentu saja ia bergerak dalam bidang pendidikan dan da'wah. Madrasah yang didirikannya semakin lama semakin maju, di samping sejumlah rumah-rumah ibadah.

Walaupun PERTI lahir sebagai organisasi non politik, namun ia tak lepas dari kegiatan politik memperjuangkan kemerdekaan bangsa. Pada Muktamar III di tahun 1941, PERTI membentuk kepanduan Al-Anshar, terilhami dengan nama kaum Anshar pembela Islam di zaman Nabi Muhammad SAW. Kemudian dalam suasana perjuangan fisik melawan kolonial Belanda pasca kemerdekaan tahun 1945, PERTI membentuk laskar perjuangan dengan nama Laskar Muslimin (untuk kaum laki-laki) dan Laskar Muslimat (untuk kaum perempuan).

Gerakan tradisional lainnya di Sumatera ialah Jami'at al-Washliyah, didirikan pada 30 Nopember 1930 di Medan. Organisasi yang bermazhab Syafi iyah ini dipelopori dan dipimpin pertama oleh Abdurrahman Syihab dkk dari kelompok pengajian Maktab alIslamiyah asuhan Syekh M.Yunus dan Syekh Ja'far Hasan. Selanjutnya, Jamiah alWashliyah banyak melakukan kegiatan dakwah dan pendidikan. Sejumlah tokoh-tokohnya pun aktif dalam politik, terutama setelah mereka bergabung dalam MASYUMI. Untuk mempetahankan kemerdekaan, Al-Washliyah turut membentuk laskar bersama sejumlah

\footnotetext{
${ }^{2}$ Van Hoeve, Ensiklopedi Islam,Perang Paderi (Ikhtiar Baru, 1994), h. 66

${ }^{3}$ Van Hoeve, Ensiklopedi Islam,Perang Paderi (Ikhtiar Baru, 1994), h. 67

${ }^{4}$ Van Hoeve, Ensiklopedi Islam,Perang Paderi (Ikhtiar Baru, 1994), h. 68
} 
organisasi lainnya, dan mengeluarkan fatwa bahwa: gugur dalam mempertahankan kemerdekaan adalah mati syahid. ${ }^{5}$

\subsection{Gerakan Islam di Pulau Sulawesi}

Sementara itu di Sulawesi terdapat pula gerakan perlawanan terhadap penjajah melalui wadah pendidikan. Ada tiga ormas Islam di bidang pendidikan yang berkiprah sejak zaman penjajahan, yaitu As'adiyah, Darud Dakwah Wal-Irsyad (DDI) keduanya di Sulawesi Selatan (Sulsel) dan Al-Khairat di Sulawesi Tengah (Sulteng). Salah seorang ulama yang berperan dalam pengembangan pendidikan Islam di Sulsel, dalam bentuk madrasah (sekolah modern), ialah Haji Muhammad As'ad. Ia lahir di Mekah, pada tanggal 12 Rabi ul Akkhir 1326 H bertepatan dengan tanggal 14 Mei 1908 M, putera dari Haji Abdur Rasyid Al-Bugisy, ulama Bugis yang bermuqim di Mekah. Pada tahun 1929, di usianya yang masih muda, masih 21 tahun ia kembali ke tanah air, dan langsung bermuqim di tanah leluhurnya, Wajo Sulsel. Sejak bulan Mei 1930, ia membuka pendidikan formal dalam bentuk madrasah modern, tidak lagi berupa halaqah. Madrasah itu diberi nama Madrasah Arabiyah Islamiyah (MAI). Dapat dikatakan bahwa lewat MAI inilah, Kiyai As'ad telah melakukan "penangkaran" ulama, yang melahirkan sejumlah ulama besar di Sulsel, antara lain: Haji Abdurahman Ambo Dalle (Barru, Pare-pare dan Pinrang), Haji Daud Islamil (Soppeng), Haji Hobe, Haji Muhammad Yunus Maratan (Wajo), Haji Muhammad Abduh Pabbaja (Pare-pare), Haji Muhammad Amberi Said (Mangkoso Barru), Haji Junaid Sulaiman (Bone), Haji Muhammad Yusuf Hamzah (Wajo), Haji Abdul Muin Yuuf (Sidenreng), Haji Muhammad Amin Nashir (Barru), Haji Marzuki Hasan (Sinjai), dan lain-lain. ${ }^{6}$

Pemikirannya yang bernuansa cinta tanah air ditandai dengan bahasa pengantar yang digunakannya, baik dalam mengajar maupun dalam menulis buku-bukunya. Meskipun ia sangat mahir dan fasih berbahasa Arab, dan para santrinya sendiri sudah menguasi bahasa Arab, buku-buku yang ditulisnya banyak menggunakan bahasa Bugis, bahkan ada yang menggunakan bahasa Indonesia. Sepeninggalnya, MAI diubah namanya oleh para murid dan pengikut beliau menjadi Madrasah As'adiyah (MA) Sengkang Wajo ${ }^{7}$

Salah seorang murid cerdas dan pewaris keilmuan Kiyai As`ad ialah Haji Abdurrahman Ambo Dalle (Kiyai Ambo Dalle). Ia telah member "ijazah" tanpa tertulis (semacam pengakuan ilmu dan izin mengajar) kepada murdinya, Ambo Dalle, untuk menyampaikan ilmu agama ke tengah masyarakat. Bahkan ia mempercayakannya memimpin MAI yang didirikannya itu. Seiring dengan itulah, popularitas Ambo Dalle, sang muridpun semakin merebak ke suluruh pelosok Sulsel dan sekitarnya. Banyak penguasa lokal yang tertarik untuk membuka cabang MAI di wilayahnya, namun tidak memeroleh izin dari Kiyai As'ad bahkan sampai wafatnya Kiyai As`ad, MAI tetap tidak membuka cabang di luar Wajo.

Salah seorang penguasa lokal ketika itu ialah Muhammad Yusuf Andi Dagong, bergelar Petta Soppeng. Ia adalah Raja di Soppeng Riaja (Soppeng bagian Barat). Andi Dagong bukannya behasrat membuka cabang MAI yang ada di Sengkang Wajo, melainkan berhasrat untuk meminta Kiyai As`ad mengizinkan Kiyai Ambo Dalle hijrah ke Soppeng Riaja untuk mendirikan madrasah tersendiri, yang tidak ada kaitannya dengan MAI Sengkang. Dengan perasaan berat, akhirnya Kiyai As`ad melepas Ambo Dalle, murid kesayangannya itu berangkat ke Soppeng Riaja, memenuhi permohonan Petta Soppeng dan masyarakat di Soppeng Riaja. Tepat hari Rabu, tanggal 21 Desember 1938 (29 Syawal 1357,

\footnotetext{
${ }^{5}$ Van Hoeve, Ensiklopedi Islam,Perang Paderi (Ikhtiar Baru, 1994), h. 68

${ }^{6}$ Azhar Arsyad dkk., Ke DDI-an,Sejarah dan Pandangan atas Isu-isu Kontemporer (Makassar: LKPMP- PB DDI, 2005), h. 18-21.

7 Azhar Arsyad dkk., Ke DDI-an,Sejarah dan Pandangan atas Isu-isu Kontemporer (Makassar: LKPMP- PB DDI, 2005), h. 21.
} 
Kiyai Ambo Dalle bersama keluarganya berangkat ke Mangkoso Soppeng Riaja, diiringi oleh beberapa santrinya. Di sinilah ia mendirikan Madrasah Arabiyah Islamiyah (MAI) tersendiri, tak ada kaitan dengan MAI Sengkang pimpinan Kiyai As`ad. Madrasah ini tidak mendapat rintangan dari penjajah Belanda, karena mendapat perlindungan dari Petta Soppengyang sekaligus menjabat sebagai Zelfbestuur untuk daerahnya. ${ }^{8}$

Keadaan berubah tatkala pasukan Jepang mendarat di Makassar pada tanggal 9 Pebruari 1942. Ketika Jepang menguasai sepenuhnya daerah Sulsel, dan mengawasi gerak-gerik masyarakat termasuk institusi pendidikan, maka MAI Mangkoso mengalami gangguan tersebut. Untuk menyelamatkan MAI, maka Ambo Dalle memindahkan kegiatan belajarmengajar untuk sementara di masjid dan di rumah-rumah tempat tinggal ustadz-nya. Karena waktu itu, belum ada kaca riben, maka kaca jendela dan pintu terpaksa dicat hitam, guna menghindari pantauan pasukan dan mata-mata Jepang. Salah satu upaya Ambo Dalle untuk mengurangi kecurigaan Jepang terhadap dirinya dan para santrinya, ialah mengarang lagulagu Bugis yang nada dan iramanya persis sama dengan lagu-lagu Jepang. Sepintas jika dinyanyikan dari jauh, lagu-lagu Bugis itu kedengaran persis sama dengan lagu-lagu perjuangan pasukan Jepang.

Keadaannya lebih parah lagi ketika pasukan Sekutu menyerbu Sulsel dan menaklukkan pasukan Jepang. Kekhawatiran semakin menghantui pimpinan, guru dan para santri MAI, akan datangnya pembalasan dari tentara Sekutu yang membabi buta menyerang dan menewaskan warga tanpa pandang buluh. Untuk menghindari pengintaian itu, kadang belajar malam dilaksanakan tanpa lampu penerang. Dengan cara yang serba susah itu, ternyata MAI mengalami perkembangan, dan akhirnya dapat membuka kelas baru untuk tingkatan Aliyah, yang lebih tinggi sebelumnya. Di samping jenjang pendidikan baru dibuka di Mangkoso, MAI juga membuka cabang di daerah sekitar Soppeng Riaja, bahkan ada cabang yang dibuka di Majene (Baruga) yang jaraknya dari Mangkoso sekitar $200 \mathrm{~km}$. ke arah utara. ${ }^{9}$

Keganasan tentara Belanda di bawah pimpinan Westerling yang memboceng Sekutu semakin keras dialamai oleh warga Sulsel, termasuk pimpinan, guru dan santri MAI Mangkoso. Ada sejumlah guru MAI yang mengalami siksaan Belanda, bahkan tewas, di antaranya ialah M. Shaleh Bone dan Sofyan Toli-toli, yang ditugaskan mengajar di Majene. Tekad melakukan perlawanan terhadap penjajah, semakin merebak ke segenap warga MAI, mulai dari pimpinannya, guru-guru sampai pada sanrinya. Secara fisik, Ambo Dalle memang tak pernah mengangkat senjata, namun kharisma yang dimiliki membuat sosok pribadinya dihormati dan disegani oleh para pimpinan pejuang di Sulsel. Ketika laskar pemuda pejuang Sulsel yang tergabung dalam Tentara Republik Indonesia Persiapan Sulawesi (TRIPS) di bawah pimpinan Andi Mattalatta hendak melakukan ekspedisi ke Jawa, mereka datang meminta doa restu Kiyai Ambo Dalle. Begitupun ketika mereka kembali dari Jawa, dan dalam persiapan melakukan konferensi kelaskaran di Paccekke Baru yang berlangsung 20 Januari 1947, berdasarkan mandat dari Panglima Besar Sudirman, mereka kembali lagi memohon doa restu dari Kyai Ambo Dalle. Diketahui bahwa konferensi kelaskaran tersebut sepakat melahirkan Divisi TRI Sulawesi Selatan/Tenggara (Sultra) sebagai embrio Kodam XIV Hasanuddin (kini Kodam VII Wirabuana). ${ }^{10}$

Demikian kiprah Ambo Dalle, ulama kharismatik yang berjuang untuk tanah air Indonesia lewat pendidikan Islam modern yang memadu dengan sistem tradisional di Sulsel.

\footnotetext{
${ }^{8}$ Azhar Arsyad dkk., Ke DDI-an,Sejarah dan Pandangan atas Isu-isu Kontemporer (Makassar: LKPMP- PB DDI, 2005), h. 22.

${ }^{9}$ Azhar Arsyad dkk., Ke DDI-an,Sejarah dan Pandangan atas Isu-isu Kontemporer (Makassar: LKPMP- PB DDI, 2005), h. 23

10 Van Hoeve, Gerakan Nasionalisme Islam yang bercorak pemurni (puritanis) dalam Ensiklopedi Islam, "Salafiyah", (Jakarta: Ikhtiar Baru, 1994), Jil. 4, h. 203.
} 
Dalam perkembangan selanjutnya, Ambo Dalle bersama dengan rekannya, Daud Ismail, dan Muhammad Abduh Pabaja menyelenggarakan Musyawarah Alim Ulama Ahlus Sunnah di Watansoppeng pada tahun 1947, tepatnya 5 s.d. 7 Feberuari 1947 (14 s.d. 16 Rabi ul Awwal $1366 \mathrm{H})$. Musyawarah tersebut dihadiri oleh sejumlah pimpinan madrasah (pesantren) di Sulsel waktu itu, yang sepakat untuk membentuk organisasi yang bergerak di bidang pendidikan dan dakwah, dengan nama Darul Da'wah wal Irsyad (DDI). Dengan terbentuknya DDI, maka sejumlah pesantren (madrasah) berintegrasi ke dalam ormas tersebut.

Jika di Sulsel ada DDI maka di Sulawesi Tengah (Sulteng) ada ormas Islam AlKhairat. Al-Khairat juga merupakan ormas di bidang dakwah dan pendidikan yang mewarnai kebangkitan bangsa di Sulteng. Ormas ini pada awalnya berupa madrasah, yang didirikan oleh Sayyid Idrus al-Jufri seorang guru dan ulama asal Hadrami yang membangun isnstitusi pendidikan modern dengan semangat pengorbanan disaat kolonial Belanda masih menjajah bangsa kita. S. Idrus al-Jufri (lahir 14 Sya'ban 1309 H/1889 M) adalah warga keturunan Arab asal Hadramaut, Yaman, putera dari pasangan Salim bin Alawi al-Jufri dan isterinya asal Wajo Sulsel yang keluarganya telah bermuqim di Yaman. Sepeningal ayahnya, ia menempati posisi sebagai Mufti pengganti ayahnya. ${ }^{11}$

Situasi politik di Yaman akibat konflik yang tidak kunjung berakhir yang melibatkan penguasa lokal, Inggris dan Dinasti Usmaniah pada perang Dunia ke I, telah menjadikan hidup semakin lebih sulit bagi orang-orang Hadrami. Dengan didorong oleh semangatnya sebagai warga Indonesia, maka pada tahun 1925 akhirnya S. Idrus al-Jufri kembali ke Indonesia, tanah leluhur dari pihak ibunya sendiri. Pada mulanya beliau tinggal beberapa tahun di Batavia dan mengajar di beberapa madrasah Jami'ah al-Khair. Sesudah itu, berpindah ke Jombang, sebuah kota pusat Islam tradisioal di Jawa Timur, dan di sanalah bertemu dengan Hasyim Asy'ari, Pendiri ormas Nahdhatul Ulama (NU). Kemudian pidah ke Solo dan mengajar di sekolah binaan kaum Alawiyin (keturunan Ali bin Abi Thalib), alRabithah al-Alawiyah.

Pada tahun 1930, ia menuju Palu, kota kediaman keluarga besar ibunya. Di sinilah ia bermukim dan beberapa bulan kemudian berhasil mendirikan madrasah yang diresmikan pada 14 Muharram 1349 H/ 30 Juni 18930 M, dengan nama Al-Khairat al-Islamiyyah.yang menjadi salah satu cikal bakal pendidikan modern di kawasan Timur Indonesia. Dengan dibantu oleh dua orang keponakannya, S.Muhammad bin al-Jufri dan S. Saggaf bin al-Jufri, Madrasah al-Khairat mengalami perkembangan pesat, membuka cabang-cabang di daerah lain dan sudah dapat menghasilkan banyak alumni.

Pada saat sebagian besar wilayah Nusantara masih dikuasai oleh kolonial Belanda, termasuk Sulteng, maka S. Idrus al-Jufri berjuang bersama lembaga pendidikannya itu menghadapi tekanan kolonial Belanda. Hal itu terutama dialami menjelang dan selama Perang Dunia II. Jasa besar S. Idrus al-Jufri ialah telah mencerdaskan warga bangsa, khususnya masyarakat Islam di Sulteng dan di kawasan Timur Indonesia. Ia juga telah menanamkan rasa harga diri kebangsaan Indonesia melalui madrasah Al-Khairat dalam menghadapi penjajah Belanda. Ia menjaga pentingnya persatuan bangsa, dimulai dari menjaga agar mayarakat Islam tidak berpecah belah. Karena itu dalam mengembangkan dakwah dan pendidikannya, sangat bersikap moderat, bahkan tidak pernah bertentangan dengan kebudayaan lokal setempat. Hal itu dilakukannya untuk merangkul umat dengan segala elemennya dalam persatuan menghadapi tekanan kolonial Belanda. Ia telah berhasil menyadarkan bangsa bahwa di samping bertujuan untuk kemajuan teknoligi dan ekonomi,

\footnotetext{
${ }^{11}$ Van Hoeve, Gerakan Nasionalisme Islam yang bercorak pemurni (puritanis) dalam Ensiklopedi Islam, "Salafiyah", (Jakarta: Ikhtiar Baru, 1994), Jil. 4, h. 204.
} 
pendidikan adalah upaya mempersatukan suku, budaya, ras, dan agama yang berbeda menjadi satu nation, yaitu bangsa Indonesia. ${ }^{12}$

\subsection{Gerakan Islam di Pulau Jawa}

Di samping gerakan keislaman tradisional di atas, tidak sedikit pula gerakan pembaharuan yang bergerak di bidang dakwah dan pendidikan. Telah disinggung sebelumnya Sumatera Thawalib. Namun gerakan pembaharuan Islam yang lebih luas melebihi gerakan Sumatera Thawalib, terjadi di Jawa dengan lahirnya organisasi yang bernama Muhammadiyah, didirkan di Yogyakarta pada tanggl 18 Nopember 1912. K.H.Ahmad Dahlan (lh.1868), pendiri Muhammadiyah pernah belajar di Mekah, ketika dua kali memperoleh kesempatan menunaikan ibadah haji (terakhir 1902). Baliau adalah pengagum Ibnu Taimiyah, sekaligus pengikut ide-ide pembaharuan Muhammad Abduh dan Rasyid Ridha lewat Tafsir Al-Manar, serta ide-ide perjuangan Jamaluddin Afghani lewat majalah Al-'Urwat al-Wutsqa. Ide-ide pembaharuan dan gerakan menentang kolonial Barat ditanamkan melalui madrasah Muhammadiyah yang didirikannya. Beliau menfokuskan diri pada amal sosial sebagai bentuk khas perjuangannya, sampai Bung Karno pernah menjulukinya "Sepi ing pamrih, rame ing gawe" (sedikit bicara tapi banyak kerja). Watak seperti ini pula yang menjadi jati diri Muhammadiyah yang didirikannya itu.

Dari kalangan kaum intelektual, banyak tertarik pada Muhammadiyah, di antaranya ialah Bung Karno sendiri, karena paham keagamaannya yang bercorak rasional. Sejalan dengan itu, Muhammadiyah juga memperbanyak sekolah moderen dengan spirit pembaharuan dan kemerdekaan. Untuk hal ini, Muhammadiyah menggalak-kan pula kegiatan kepanduan bernama "Hizbul Wathan" pada tahun 1920, yang pernah dibina oleh Sarbini dan Panglima Besar Sudirman. ${ }^{13}$

Tak dapat dipungkiri, tokoh-tokoh Muhammadiyah banyak terlibat secara pribadi dalam Partai Sarikat Islam Indonesia (PSII) di bawah pimpinan H.O.S. Cokroaminoto, dan sebahagian lagi dalam Partai Nasional Indonesia (PNI) pimpinan Bung Karno. Bersama dengan pejuang nasionalis lain, Muhammadiyah sangat gigih memperjuangkan pendidikan bagi kaum pribumi. Muhammadiyah juga sangat menentang kebijaksanaan Belanda yang tidak adil dalam masalah keagamaan, dan tak kalah pentingnya, Muhammadiyah mendukung gerakan kebangsaan untuk lahirnya Parlemen Indonesia. ${ }^{14}$

Memasuki era Jepang, kepemimpinan organisasi Muhammadiyah berada di tangan K.Bagus Hadikusumo menggantikan K.H.Mas Mansyur. Sebagai anggota Panitia Persiapan Kemerdekaan Indonesia (PPKI), beliau banyak berjasa dalam perumusan Mukadimah Undang-Undang Dasar 1945, dan bersama tokoh Islam lainnya, Wahid Hasyim, H.Agus Salim dan Kasman Singodimejo tidak keberatan dicoretnya tujuh kata: "dengan kewajiban menjalankan syariat Islam bagi pemeluk-pemeluknya" dari teks Pancasila sehingga menjadi: Ketuhanan Yang Maha Esa. ${ }^{15}$

Mirip dengan Muhammadiyah, lahir pula gerakan Islam yang bernama Persatuan Islam (PERSIS), didirkan oleh K.H. Zamzam pada tanggal 17 September 1923 di Bandung. Pimpinan PERSIS yang paling populer ialah A. Hassan yang bergabung sejak tahun 1926, beliau pernah aktif surat menyurat dengan Bung Karno ketika Bung Karno dibuang Ke Ende. Organisasi ini juga mengutamakan aspek pendidikan, sekolah atau pesantren, dan kegiatan

\footnotetext{
${ }^{12}$ Van Hoeve, Gerakan Nasionalisme Islam yang bercorak pemurni (puritanis) dalam Ensiklopedi Islam,

"Salafiyah", (Jakarta: Ikhtiar Baru, 1994), Jil. 4, h. 205

${ }^{13}$ Gerakan Politik Islam Indonesia, http//Islam-Rahmah.com tgl 21-11-18

${ }^{14}$ Gerakan Politik Islam Indonesia, http//Islam-Rahmah.com tgl 21-11-18

15 Gerakan Politik Islam Indonesia, http//Islam-Rahmah.com tgl 21-11-18
} 
dakwah Islam secara luas. Dalam berbagai aktifitasnya, gerakan ini membangun kesadaran umat untuk pembaharuan sosial dan kemerdekaan bangsa.

Tokoh PERSIS yang aktif dalam politik ialah Mohammad Natsir, berasal dari Alahan Panjang Sumatera Barat. Natsir sangat fasih dalam pidato dan mahir dalam tulisan. Beliau bergabung di PERSIS tahun 1927, juga pernah aktif dalam Jong Islamieten Bond (J.I.B), perkumpulan pemuda Islam yang ikut mendeklarasikan Sumpah Pemuda tanggal 28 Oktober 1928. Beliau adalah model ulama intelek atau intelek ulama yang akhirnya lebih dikenal sebagai tokoh Masyumi, ketimbang sebagai warga PERSIS. ${ }^{16}$

Kesadaran nasionalis rupanya juga tumbuh di kalangan warga keturunan Arab yang hidup di Indonesia. Gerakan ini dipelopori oleh Sayid Muhammad Al-Fakhir bin Abdurrahman al-Manshur dan Sayid Idrus Ahmad bin Shahab. Mereka mendirikan organisasi Jamiat al-Khayr yang memperoleh izin pendirian dari Belanda di tahun 1905. Tidak kurang, K.H.Ahmad Dahlan dan H.O.S. Cokroaminoto, yang masing-masing adalah pemimpin Muhammadiyah dan Sarekat Islam, pernah aktif dalam organisasi tersebut. K.H.Ahmad Dahlan tertarik pada luasnya jaringan organisasi ini dengan negeri Muslim lain, yang ketika itu masih di bawah KhilafahTurki Usmaniiyah

Berdiri pula Al-Rabithah al-Alawiyah, perkumpulan keluarga Arab Alawiyah, tahun 1928 di Jakarta, yang tujuannya adalah mewujudkan kesejahteraan orang Arab kaum Alawiyah. Berbagai kegiatan sosialnya telah mengangkat kesejahteraan umat Islam Indonesia pada umumnya, tidak hanya keturunan Arab. Dua organisasi warga Arab di atas, telah berjasa besar menanamkan rasa keindonesiaan pada warga keturunan Arab dan menjalin pembauran antara keturunan Arab dan Indonesia asli.

Keadaan rakyat Indonesia yang masih terkebelakang di bidang pendidikan, dan masih sangat miskin menjadi perhatian dari gerakan keislaman pada umumnya. Di Jawa Barat, K.H.Ahmad Halim dari Majalengka mendirikan organisasi Persatuan Oemat Islam (POI) di tahun 1917. Kegiatannya ialah amal sosial dan pendidikan, banyak mendirikan Madrasah Ibtidaiyah (1917) dan Madrasah Muallimin (1923). Tapi, jasanya yang paling spektakuler ialah didirikannya sebuah perguruan tinggi di atas bukit, yang diberi nama Santi Ashrama. Perguruan ini, memadu pelajaran agama dengan pelajaran umum, bahkan sejumlah keterampilan bertani dan indsutri rumah tangga. ${ }^{17}$

Sebelumnya, semangat yang sama juga telah diemban oleh Mathla'ul-Anwar, yang lahir pada tahun 1905 di Menes Jawa Barat. Organisasi ini didirikan oleh K.H.M.Yasin, juga banyak mendirikan sekolah-sekolah sebagai media penyebaran wacana pembaharuan sosial. Di bidang politik, di bawah kepemimpinan K.H.Abdurrahman, organisasi ini bekerjasama dengan Sarekat Islam (S.I) dalam menentang Belanda.

Gerakan Islam yang paling spektakuler karena kedekatannya kepada kaum tradisional Islam, bahkan menjadi pengawal kaum tradisional, ialah Jamiah Nahdhatul Ulama (NU). Organisasi kaum ulama ini, memelihara hubungan kultural dengan masyarakat awam dengan tetap memberi peluang bagi berlakunya sejumlah tradisi yang tidak bertentangan dengan prinsip akidah. Bahkan peninggalan tradisi leluhur, dibiarkan tumbuh dengan baju keIslaman, dalam kemasan baru acara-acara selamatan. Warisan peradaban lama, seperti candi, dibiarkan terpelihara dengan baik, mencontoh nasionalisme Islam di Mesir yang membiarkan piramid-piramid berdiri kokoh di tengah padang pasir. Maka tak salah jika dikatakan bahwa gerakan kultural NU ini sangat bercorak ke-Indonesiaan, sehingga paham kebangsaan menjadi jati dirinya. ${ }^{18}$

16 Gerakan Politik Islam Indonesia, http//Islam-Rahmah.com tgl 21-11-18

17 Gerakan Politik Islam Indonesia, http//Islam-Rahmah.com tgl 21-11-18

${ }^{18}$ Gerakan Politik Islam Indonesia, http//Islam-Rahmah.com tgl 21-11-18 
Sejalan dengan gerakan kebangkitan nasional Budi Utomo 1908, kalangan pesantren tak kalah gigihnya melawan panjajah Belanda. Mereka membentuk organisasi kebangkitan, seperti Kebangkitan Tanah Air (Nahdhatul Wathan) pada tahun 1916. Organisasi ini mendirikan madrasah, kursus dan kegiatan diskusi yang dipimpin oleh K.H.Wahab Hasbullah. ${ }^{19}$ Ketika Wahab Hasbullah sedang aktif dalam gerakan diskusi dan kursus agama yang dipimpinnya, begitupun dalam Indonesische Studie Club yang didirikan oleh Dr. Sutomo, topik yang hangat ketika itu ialah dibubarkannya khilafah di Turki dan soal berkuasanya Ibnu Saud di Hijaz. Ibnu Saud yang dikenal beraliran Wahabiyah ingin memberlakukan mazhab tunggal Hanbali. Kalangan pesantren yang menghargai pluralitas dan tradisi serta peninggalan warisan keindonesiaan tidak menerima rancana Raja Ibnu Saud tersebut. Mereka menuntut berlakunya empat mazhab (Hanafi, Maliki, Syafi'i dan Hanbali), dan menghimbau pemerintah Ibnu Saud agar menghormati keragaman mazhab, serta melindungi makam-makam dan tempat-tempat bersejarah lainnya dari penghancuran. Delegasi yang dibentuk untuk menghadiri kongres khilafah di Makkah, diberi nama Komite Hijaz. Komite ini pada akhirnya dideklarasikan menjadi organisasi Jami ah Nahdhatul Asy'ari. ${ }^{20}$

Kesadaran nasional dan menjadikan bahasa Indonesia sebagai bahasa resmi adalah tuntutan utama organisasi NU. Bersama-sama dengan Muhammadiyah, NU turut memperjuangkan Indonesia berparlemen. NU juga sangat menentang peraturan produk Belanda: "Guru Ordonansi" yang dipandang tidak sesuai dengan perjuangan kemerdekaan Indonesia.

Di antara sekian tokoh NU yang aktif dalam perjuangan kemerdekaan, tercatat nama K.H.Wahid Hasyim, putera pendiri NU, Hasyim Asy`ari, proaktif dalam Panitia Persiapan Kemerdekaan Indonesia (PPKI). Bahkan beliau juga menjadi salah satu anggota Panitia Sembilan yang merumus secara final dasar negara Republik Indonesia, Pancasila. Lebih hebat lagi, kalangan intelektual di luar pesantren mendirikan perkumpulan kepemudaan yang diberi nama Jong Islamieten Bond (JIB) pada tanggal 1 Januari 1925 di Jakarta. Anggota JIB pada umumnya berasal dari pelajar dan alumni dari MULO dan AMS dipelopori oleh Samsurijal, yang sebelumnya adalah Ketua Jong Java. Kongres I JIB di Yogyakarta (1925) yang memilih Samsurijal menjadi Ketua Umum, juga menetapkan Kasman Singodimejo sebagai salah seorang komisaris. Kemudian pada Kongres JIB tahun 1929 di Jakarta, Kasman Singodimejo terpilih menjadi Ketua. Kasman brsama Muhammad Rum tercatat sebagai alumni dari kepanduan Natipij (National Indonesische Padvinderij) yang dibentuk oleh JIB.

Langkah proaktif mempersiapkan deklarasi Sumpah Pemuda, diambil oleh JIB dengan menunjuk Djohan Muhammad Tjaja menjadi anggota panitia pada Kongres Pemuda II bulan Juni 1928. Tak dapat dipungkiri, betapa besar peranan JIB dalam deklarasi Sumpah Pemuda. dan adalah Djohan Muhammad Tjaja bertindak atas nama JIB bertanda tangan dalam naskah Sumpah Pemuda tersebut. Jasa besar JIB sebagai organisasi intelektual dan kepemudaan Islam ialah, bahwa ia menggaungkan kebangkitan nasionalisme Indonesia secara monumental. Maka tidak heran nanti, jikalau Kasman Singodimejo, salah seorang alumni JIB juga aktif dalam PPKI untuk merumuskan pembukaan UUD $1945 .^{21}$

Tokoh JIB yang cukup penting dan tak dapat dilupakan ialah Muhammad Natsir. Kiprah beliau tidak hanya sebelum kemerdekaan, tetapi juga setelah kemerdekaan tetap menghiasi perjuangan keislaman nasionalis. Natsir pernah menjadi menteri dalam Kabinet Syahrir ke 2 dan ke3, dalam Kabinet Hatta 1 sebagai Menteri Penerangan RI. Bahkan

${ }^{19}$ Ensiklopiedi Islam,., vol. 4, h. di unduh tgl 21-11-18

${ }^{20}$ Ensiklopiedi Islam,., vol. 4, h. diunduh tgl 21-11-18

${ }^{21}$ Ensiklopiedi Islam,., vol. 4, diunduh tgl 21-11-18 
akhirnya menjadi Perdana Menteri RI tahun 1950-1051. Perbedaan pandangan dengan Bung Karno dalam berbagai hal, tidak menghalangi Natsir untuk sepakat dalam soal nasionalisme, sebagaimana katanya:

"Soal Pancasila sebagai dasar negara sudah tidak dipersoalkan lagi. Menurut Undang-undang Dasar 1945 dasar negara kita adalah Ketuhanan Yang Maha Esa (pasal 29 ayat 1). Tapi sudah menjadi kebiasaan untuk mengatakan bahwa dasar negara Republik Indonesia adalah Pancasila. Memang ke lima-lima sila dari Pancasila itu terkandung dalam Mukaddimah UUD '45. Presiden Soekarno memperkenalkannya dengan istilah "Welt-Anschaung”, yakni Falsafah Negara Republik Indonesia”. ${ }^{22}$

\subsection{Kegiatan di Bidang Politik}

Semua gerakan dan organisasi Islam seperti disinggung di atas adalah punya perjuangan politik menghadapi penjajahan, baik langsung maupun tidak langsung. Namun, ada satu organisasi Islam yang paling menonjol dalam politik ialah Sarikat Islam (Sarikat Dagang Islam), yang kemudian berubah menjadi Partai Sarekat Islam Indonesia (PSII) pada tahun 1911. Bermula masih dalam bentuk usaha dagang, Sarekat Dagang Islam (SDI) didirikan pada tahun 1909 di Bogor, kemudian di Solo, dengan media surat kabarnya Sarotomo. SDI didirikan untuk memberdaya-kan kekuatan ekonomi kaum pribumi berpacu dengan keturunan Tionghoa yang sudah punya hubungan baik dengan Belanda. SDI kemudian resmi bernama Sarekat Islam (SI), atas prakarsa H.Oemar Said Tjokroaminoto, seorang yang sangat gigih melawan Belanda.

Kongres pertama SI di Surabaya pada tanggal 26 Januari 1913 membentuk Komite Sentral dan menunjuk H.Samanhudi sebagai ketua, H.O.S. Cokroaminoto sebagai wakilnya. Kongres juga menetapkan corak pergerakan SI yang bersifat sosial ekonomis atas landasan nasionalisme dan keislaman. Anggaran Dasar S.I. akhirnya diakui oleh pemerintah kolonial di tahun 1916. SI memperjuangkan dihapusnya kerja paksa, penurunan pajak, pemerataan pendidikan dan perbaikan pertanahan untuk rakyat kecil. Tetapi perjuangannya untuk mengadakan Parlemen bagi anak negeri sendiri tidak berhasil. Hal itu semakin mengobarkan semangat juang SI, yang sejak 1919 dan sesudahnya, menyebarkan slogan membangkitkan semangat perlawanan terhadap penjajah yang kapitalis. ${ }^{23}$

Sebahagian pengurus lokal SI yang berhaluan sosialis pro Komunis, menuntut dijadikannya SI seperti gerakan internasionalist komunis. Perjuangan SI mengalami gangguan, yang berakibat pecahnya SI menjadi dua, SI Merah dan SI Putih; mereka yang pro Komunis menyebut dirinya sebagai SI Merah. Mereka yang konsisten pada ajaran sosial Islam berhasil kemudian mendirikan partai politik dengan nama PSI (Partai Sarikat Islam) sesuai dengan ketetapan Kongres SI Maret tahun 1921. Unsur komunis yang dikeluarkan dari dalam tubuh SI memisahkan diri dan membentuk pula partai baru, Partai Komunis Indonesia (PKI). ${ }^{24}$

Eskalasi perjuangan semakin terjadi, ketika pada tahun 1924 PSI tidak lagi mendudukkan wakilnya dalam Dewan Rakyat (Volksraad) produk kolonial, sebagai bentuk protes, guna memperkuat tuntutannya agar Indonesia berparlemen. PSI sudah terangterangan menempuh perjuangan non cooperatie, atau politik hjrah, yang berarti PSI sudah tidak mau lagi bekerja besama dengan pemerintah kolonial. Sikap ini dikukuhkan oleh Kongres Al-Islam yang berlangsung di tahun itu juga. Sikap non koperatif dengan Belanda semakin meluas di kalangan Bangsa Indonesia, sampai masuknya Jepang (1942-1945).

\footnotetext{
${ }^{22}$ M.Natsir, Asas Keyakinan Agama Kami, (Jakarta: Dewan Dakwah Islamiyah Indonesia, 1982), h.1

${ }^{23}$ Gerakan Politik Islam Indonesia, http//Islam-Rahmah.com tgl 21-11-18

${ }^{24}$ Gerakan Politik Islam Indonesia, http//Islam-Rahmah.com tgl 21-11-18
} 
PSI kemudian berubah nama menjadi PSII (Partai Sarekat Islam Indonesia) pada tahun 1930. Tahun-tahun sesudahnya sampai masuknya Jepang, PSII mengalami sejumlah persoalan internal partai. Pada awalnya, soliditas PSII cukup nyata di bawah pengaruh dua tokoh besar, Tjokroaminoto dan H.Agus Salim, ibaratnya perpaduan Bung Karno dan Bung Hatta. Namun, ketika Abi Kusno Tjokrosujoso memimpin PSII, sepeninggal Tjokroaminoto, ia memecat H.Agus Salim. Menyusul kemudian Sukiman juga dipecat pada tahun 1933, yang mendorong lahirnya faksi baru, Partai Islam Indonesia (PII). Terlepas dari sejumlah krisis internal tersebut, dua tokoh penting PSII, Abi Kusno Tjokrosujoso dan Agus Salim memainkan peran penting dalam Panitia Persiapan Kemerdekaan Indonesia (PPKI), yang bertugas menyusun mukadimah (pembukaan) Undang-Undang Dasar $1945 .^{25}$

\section{Kesimpulan}

Nasionalisme di kalangan umat Islam Indonesia telah tumbuh sejak sejumlah kesultanan di tanah air melawan Belanda. Perlawanan para kesultanan itu adalah perang fisik melawan Belanda. Setelah Belanda menaklukkan hampir semua kesultanan dan kerajaan lokal, sehingga Belanda menguasai Indonesia sepenuhnya, maka bentuk perlawanan pun kemudian berubah. Perubahan bentuk perjuangan ditandai dengan lahirnya pergerakan keislaman, baik dalam bentuk madrasah (sekolah), organisasi massa, maupun partai politik. Kesadaran akan semangat nasionalisme terbentuk dari zaman kesultanan, yang kemudian terus tumbuh di kalangan ormas-ormas Islam, akhirnya semakin mengkristal dalam tubuh partai-partai politik.

Rentetan perjuangan tersebut semakin mematangkan nasionalisme Islam Indonesia untuk turut serta mengantarkan bangsa Indonesia ke pintu kemerdekaannya. Aktitiftas tokohtokoh pergerakan keislaman dari kalangan pesantren, pedagang, politisi, pemuda dan intelektual semakin intensif ketika mereka menjadi anggota PPKI yang bertugas menyusun Undang-Undang Dasar 1945.

Hasil dari keseluruhan rentetan panjang perjuangan keislaman tersebut akhirnya terangkum dalam simpul Pancasila, sebagai dasar negara, seperti yang ada sekarang. Pancasila, sila pertama yang awalnya berbunyi "dengan kewajiban menjalankan syariat Islam bagi pemeluk-pemeluknya" itu adalah bukti andil besar muslim Indonesia dalam merebut kemerdekaan, yang walaupun akhirnya kalimat tersebut dihilangkan, demi solidaritas dan persatuan rakyat Indonesia yang terdiri dari berbagai suku dan agama.

\section{Daftar Pustaka}

Soekarno, Dibawah Bendera Revolusi, (Jakarta: Panitia, 1964), Jilid I

Ensiklopedi Islam,Perang Paderi (Ikhtiar Baru Van Hoeve, 1994), Jilid IV

Azhar Arsyad dkk., Ke DDI-an,Sejarah dan Pandangan atas Isu-isu Kontemporer, (Makassar: LKPMP- PB DDI, 2005), h. 18-21.

Gerakan Nasionaisme Islam yang bercorak pemurni (puritanis). Ensiklopedi Islam, “Salafiyah”, (Jakarta: Ikhtiar Baru Van Hoeve, 1994)

Ensiklopiedi Islam

M.Natsir, Asas Keyakinan Agama Kami, (Jakarta: Dewan Dakwah Islamiyah Indonesia, 1982)

Gerakan Politik Islam Indonesia, http//Islam-Rahmah.com

\footnotetext{
${ }^{25}$ Gerakan Politik Islam Indonesia, http//Islam-Rahmah.com tgl 21-11-18
} 